\title{
Hierarchization of Zeolites A and X Using Bacterial Cellulose as Macroporous Support
}

\author{
Raquel A. Bessa, ${ }^{a, b, c}$ André Luís S. Pereira, ${ }^{a, b}$ Morsyleide F. Rosa, ${ }^{b}$ Michael W. Anderson ${ }^{c}$ \\ and Adonay $R$. Loiola ${ }^{\circledR} *, a$ \\ ${ }^{a}$ Departamento de Química Orgânica e Inorgânica, Universidade Federal do Ceará, \\ 60440-900 Fortaleza-CE, Brazil \\ ${ }^{b}$ Embrapa Agroindústria Tropical, 60511-110 Fortaleza-CE, Brazil \\ ${ }^{c}$ Centre for Nanoporous Materials, The University of Manchester, \\ Manchester M13 9PL, United Kingdom
}

\begin{abstract}
In this work, we studied the formation of hierarchical porous cartridges by means of bacterial cellulose impregnation with the zeolites A and X. Cellulose was successfully produced by Komagataeibacter genus and the zeolites were obtained by hydrothermal route. The composites were formed using both oxidized and non-oxidized cellulose. Different characterization techniques were used to analyze the resulting materials like powder X-ray diffraction, spectroscopic techniques (infrared vibrational spectroscopy and nuclear magnetic resonance), electron microscopy, thermal analyses, as well as ionic exchange experiments. The results show that the composites present layers with large voids among them, formed by cellulose nanofibrils tangling the particles in the oxidized samples, and shiftings in the bands referent to the carboxilyc groups and hydrogen bondings. The oxidation step for the cellulose seems to be important for the hierarchization and a positive effect on the cartridges is found for $\mathrm{Ca}^{2+}$ ionic exchange tests. Thus, these components can be successfully mixed to form cartridges with potential use at gas and liquid adsorption technologies.
\end{abstract}

Keywords: zeolite, bacterial cellulose, hierarchization

\section{Introduction}

Since the $18^{\text {th }}$ century, the world is facing important industrial development with benefits to society and way of living. Nevertheless, there is also the generation of toxic residues that contaminate both air and water. ${ }^{1,2}$ Currently, there are a variety of available methods for wastewater treatment such as advanced oxidation processes and membrane treatment, but they tend to be complex costly options. Therefore, new methods and materials are demanded for wastewater treatment. ${ }^{3}$ Ion exchange and adsorption present the important property of being cost-effective methods, particularly due to the wide range of materials types employed, such as fibrous materials, microporous adsorbents, wood, polymers, activated carbon, graphite oxide, nanoparticles, metal-organic frameworks (MOFs) and zeolites. ${ }^{4}$

*e-mail: adonay@ufc.br
Zeolites are microporous crystalline solids formed mainly by silica tetrahedra linked to each other by oxygen atoms, where other $\mathrm{T}$ elements ( $\mathrm{T}=\mathrm{Al}, \mathrm{Ge}, \mathrm{Fe}, \mathrm{Ga}$, Ti, etc.), either tri or tetravalent, can substitute the silicon atoms. This results in important properties, in particular strong acid sites, high specific surface area, ionic exchange capacity, thermal stability, and well-defined pore systems, which make them exceptional adsorbents for several gaseous compounds. ${ }^{5}$ For practical applications, zeolites present a limitation due to the fact that they are polycrystalline materials, so compression to pellets forms are usually required. This way, diffusional limitation related to the target molecules to access the inner sites of the porous material can restrict zeolite performance.

An approach to overcome these issues can be employed by means of the hierarchization of the pores systems, so that besides the zeolites inherent micropores, other pore systems properly interconnected are present. First attempts for implementation of additional pores systems to a porous material were done by the end of the 1960 's ${ }^{6}$ 
with mesoporosity in zeolites, but just in the 2000's ${ }^{7}$ it was further explored. Since then, several works have been published, attesting the importance of this field with advantages such as improvements in the mass transport and diffusional rates, reduction of steric limitations and facilitated transport inside and out of the porous structures. ${ }^{8}$ An alternative to obtain hierarchical materials is the combination of the zeolitic micropores with at least one second porous material. ${ }^{9,10}$

Using cellulose as macroporous supports for zeolite crystals is reported in literature by Bendahou et al., ${ }^{11}$ using oxidized date palm tree nanofibres and nanozeolite particles. As a result, the cartridges formed present improved thermal conductivity and mechanical properties, combining the inter-cellulose films mesoporosity and the zeolite microporosity. Valencia et al. ${ }^{12}$ used this approach for foams used in $\mathrm{CO}_{2} / \mathrm{N}_{2}$ separation processes. Mixing gelatin and nanocellulose from softwood fibres, colloidal zeolite silicalite-1 was impregnated with $90 \%$ of the weight. This resulted in highly mechanically stable hybrid foams in which the cellulosic matrix is not blocking the zeolite pores.

Bacterial cellulose (BC) was reported by $\mathrm{Ma}$ et al..$^{13}$ to form a composite aerogel through in situ growth of flexible metal-organic framework. The materials presented three-dimensional porous network with high porosity, low density, and good flexibility. The authors suggest that different materials could use the same approach, depending on the requirements for the application, and superior properties. In our recent work, we proposed the formation of an aerogel-like cartridge containing a zeolite A with micro and mesopores and BC nanofibres as support. Differently from that work, ${ }^{13}$ we did not use in situ approach, but impregnation of the zeolite crystals in the cellulosic matrix. The cartridges presented high surface area, and superior performance as adsorbent for $\mathrm{Pb}^{2+}$ from aqueous medium. ${ }^{14}$ So far, this seems to be the first publication using the $\mathrm{BC}$ and zeolite for this purpose, and unlikely the vegetal cellulose, the $\mathrm{BC}$ contributes with its unique properties as high purity and crystalline structure, with chemical and physical properties that can be tuned..$^{10,15,16}$

In this work, we report the preparation of hierarchical cartridges combining the nanofibrillar BC structure with two different zeolites aiming to evaluate the influence of the zeolite structure. Previous works ${ }^{11-14}$ involving cellulose and zeolite commonly study either oxidized or nonoxidized cellulose without a comparative discussion about the benefits and differences of using each of them on the properties of the composites. Using some characterization techniques, we present the synergistic effect between the $\mathrm{BC}$, depending on their partial oxidation, and the zeolites. The ionic exchange tests are used to check their potential use for adsorption systems in both gas and aqueous medium.

\section{Experimental}

\section{Chemicals}

All chemicals used were of analytical grade. Sodium hydroxide $(\mathrm{NaOH})$, sodium chloride $(\mathrm{NaCl})$, hydrochloric acid $(\mathrm{HCl})$ and calcium chloride $\left(\mathrm{CaCl}_{2}\right)$ were purchased from Vetec Química Fina (Duque de Caxias, Brazil). Sodium bromide $(\mathrm{NaBr})$ and sodium hipoclorite $(\mathrm{NaClO})$, were purchased from Dinâmica (Indaiatuba, Brazil). From Sigma-Aldrich (São Paulo, Brazil), the chemicals 2,2,6,6-tetramethylpiperidine-1-oxyl (TEMPO), sodium metasilicate $\left(\mathrm{Na}_{2} \mathrm{SiO}_{3}\right)$ and sodium aluminate $\left(\mathrm{NaAlO}_{2}\right)$ were purchased.

\section{Synthesis of zeolites}

For this study, we produced two different zeolites with differences regarding the pore dimensions and the crystal sizes: zeolites A and Y, the later as nanosized crystals. The syntheses procedures are briefly described below and were obtained via hydrothermal route.

In short, zeolite $\mathrm{A}$ was produced using a gel by mixing a silicate solution $\left(7.16 \mathrm{~g} \mathrm{Na}_{2} \mathrm{SiO}_{3}\right.$ and $35 \mathrm{~mL} \mathrm{NaOH}$ $\left.0.21 \mathrm{~mol} \mathrm{~L}^{-1}\right)$ to an aluminate solution $\left(5.00 \mathrm{~g} \mathrm{NaAlO}_{2}\right.$ and $35 \mathrm{~mL} \mathrm{NaOH} 0.21 \mathrm{~mol} \mathrm{~L}^{-1}$ ) forming a precursor gel that was aged for 1 day at room temperature (RT) in a stainless-steel autoclave and crystallized under static conditions at $100^{\circ} \mathrm{C}$ for $4 \mathrm{~h}$. Then, the solid was centrifuged several times with deionized (DI) water until constant $\mathrm{pH}$ and dried. ${ }^{5}$

To obtain zeolite $\mathrm{X}, 4 \mathrm{~mL}$ of an initial seed gel (produced mixing a silicate solution, $6.52 \mathrm{~g} \mathrm{Na}_{2} \mathrm{SiO}_{3}$ and $16 \mathrm{~mL} \mathrm{H}_{2} \mathrm{O}$, and an aluminate solution, $2.09 \mathrm{~g} \mathrm{NaAlO}_{2}$ and $20 \mathrm{~mL} \mathrm{NaOH} 5.09 \mathrm{~mol} \mathrm{~L}^{-1}$, ageing for 1 day at RT) was added dropwise to the growing gel (formed by mixing a silicate solution, $10.22 \mathrm{~g} \mathrm{Na}_{2} \mathrm{SiO}_{3}$ and $25 \mathrm{~mL} \mathrm{H}_{2} \mathrm{O}$, and an aluminate solution, $3.27 \mathrm{~g} \mathrm{NaAlO}_{2}$ and $33 \mathrm{~mL} \mathrm{NaOH}$ $0.03 \mathrm{~mol} \mathrm{~L}^{-1}$ ). The global synthesis gel after one day induction period in a Teflon-lined stainless-steel autoclave was crystallized under static conditions at $100^{\circ} \mathrm{C}$ for $7 \mathrm{~h}$. Then, the solid was centrifuged several times with DI water until constant $\mathrm{pH}$ and dried. ${ }^{5}$

\section{Bacterial cellulose production}

To produce the BC pellicles, Komagataeibacter xylinus (ATCC 53584) was used with Hestrin and Schramm (HS) ${ }^{17}$ synthetic medium. The microorganisms were activated 
in sterilized HS solution and incubated for $72 \mathrm{~h}$ in static cultivation. $3 \%(\mathrm{v} / \mathrm{v})$ of the inoculate were cultivated with the culture medium in plastic trays at $30{ }^{\circ} \mathrm{C}$ for 10 days. For purification, $\mathrm{BC}$ pellicles were immersed in water, followed by $2 \%(\mathrm{~m} / \mathrm{v}) \mathrm{NaOH}$ treatment $\left(80{ }^{\circ} \mathrm{C}, 1 \mathrm{~h}\right)$ and neutralized with DI water. ${ }^{18}$

To perform the studies about the influence of the cellulose oxidation over the cartridges formation, the non-oxidized sample $\left(\mathrm{C}_{0}\right)$ was formed disintegrating the pellicles using a high-performance blender and the product was homogenized into a $0.5 \mathrm{wt} \% \%$ suspension. The oxidized sample $\left(\mathrm{C}_{\text {oxi }}\right)$ was formed using TEMPO radical (0.048 g) under continuous mechanical stirring in a suspension with $1.0 \mathrm{~g}$ of the disintegrated sample, $0.3 \mathrm{~g}$ of $\mathrm{NaBr}, 9.24 \mathrm{~mL}$ of $\mathrm{NaClO}$ and $300 \mathrm{~mL}$ of $\mathrm{H}_{2} \mathrm{O}$. This composition was used proportionally for cellulose available. This system was kept for $2.5 \mathrm{~h}$ at $\mathrm{pH} 11$ by the addition of $\mathrm{NaOH}$. At the end, the suspension was centrifuged at $13000 \mathrm{rpm}$ for 3 times with DI water and homogenized into a $0.5 \mathrm{wt} . \%$ suspension. ${ }^{19}$

\section{Preparation of the cartridges}

The cartridges were formed by mixing $500 \mathrm{mg}$ of each zeolite and to integrate $50 \mathrm{~g}$ of the composite hydrogel, the cellulose suspension, 0.5 wt.\% in water was used, stirring magnetically for $30 \mathrm{~min}$ at RT. The composite suspension is transferred into $15 \mathrm{~mL}$ falcon tubes, following to liquid nitrogen freezing and freeze-drying. The cartridges were cut in small pieces of ca. $2 \mathrm{~cm}$ and $15 \mathrm{mg}$, using scalpels (pure cellulose samples presented simillar sizes and mass of ca. $5 \mathrm{mg}) .{ }^{14}$ Figure 1 depicts the samples used in this work and their codes.

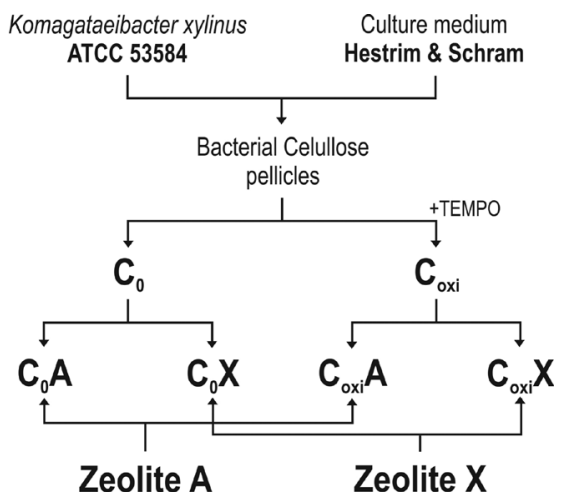

Figure 1. Scheme containing the samples' codes used for this work of cellulose $\left(\mathrm{C}_{0}\right.$ and $\left.\mathrm{C}_{\mathrm{oxi}}\right)$, zeolites (zeolites $\mathrm{A}$ and $\mathrm{X}$ ), and the respective composites with the zeolites $\left(\mathrm{C}_{0} \mathrm{~A}, \mathrm{C}_{0} \mathrm{X}, \mathrm{C}_{\text {oxi }} \mathrm{A}\right.$ and $\left.\mathrm{C}_{\text {oxi }} \mathrm{X}\right)$.

\section{Characterization}

Powder X-ray diffraction (PXRD) experiments were performed using a X-ray powder diffractometer (Panalytical
X-Pert Pro MPD, Malvern, UK) in the continuous mode with $0.5 \mathrm{~min}^{-1} 2 \theta$ scan speed. A tube of $\mathrm{Co} \mathrm{K \alpha}$ radiation was used $(\lambda=1.788965 \AA)$, operating at $40 \mathrm{kV}$ and $40 \mathrm{~mA}$. For the powders, particle sizes below $75 \mathrm{~mm}$ (200 mesh) where adjusted before analysis, whilst the cartridges were analyzed as thin circular slices pressed in the sample holder.

Fourier transform infrared vibrational spectroscopy (FTIR) spectra were acquired using Shimadzu IRealise FTIR spectrometer (Kyoto, Japan) for the samples at RT in the region $4000-400 \mathrm{~cm}^{-1}$ and nominal resolution of $2 \mathrm{~cm}^{-1}$. $\mathrm{KBr}$ pastilles were formed with all the powder and cartridge samples right before the analysis. Solid-state nuclear magnetic resonance (NMR) spectroscopy was performed on a Bruker Avance $400 \mathrm{MHz}$ spectrometer (Billerica, USA) in a $4 \mathrm{~mm}$ probe where the powders or pieces of the cartridges were pressed, at a spin rate of $12000 \mathrm{~Hz}$. The recycle delay used for recording the ${ }^{29} \mathrm{Si}$ spectra was $10 \mathrm{~s}$, while for ${ }^{13} \mathrm{C}$ and ${ }^{27} \mathrm{Al}, 5 \mathrm{~s}$.

Scanning electron microscopy (SEM) images were recorded in a FEG Quanta 450 (Thermo Fisher Scientific, Waltham, USA). Prior to the analysis, samples were prepared on aluminium stubs using a conductive carbon double-sided sticky tape and covered with a $20 \mathrm{~nm}$ gold layer. Thermogravimetric analyses (TGA) were conducted on a PerkinElmer STA 6000 analyzer (Waltham, USA) under synthetic air flow of $50 \mathrm{~mL} \mathrm{~min}^{-1}$ in the $25-800{ }^{\circ} \mathrm{C}$ temperature range $\left(\right.$ rate $\left.=10^{\circ} \mathrm{C} \mathrm{min}^{-1}\right)$. Approximately $8 \mathrm{mg}$ of each sample was used for the analysis.

The electric conductivity titration method was used to determine the carboxylate content for the oxidized cellulose sample. $1.0 \mathrm{~g}$ of the sample dispersed in $183.3 \mathrm{~mL}$ of $\mathrm{H}_{2} \mathrm{O}$ formed a well-dispersed slurry where $16.67 \mathrm{~mL}$ of $0.01 \mathrm{~mol} \mathrm{~L}^{-1} \mathrm{NaCl}$ solution was added. The starting $\mathrm{pH}$ value was adjusted to 2.5-3.0 and the mixture was titrated with ca. $50 \mathrm{~mL}$ of $0.04 \mathrm{~mol} \mathrm{~L}^{-1} \mathrm{NaOH}$. From the curve, values for the volume of $\mathrm{NaOH}$ required for the neutralization of the strong acid $(\mathrm{HCl})$, and for neutralization of the weak acid $(-\mathrm{COOH})$ were used to determine the carboxylate content and degree of oxidation. ${ }^{19,20}$

$\mathrm{Ca}^{2+}$ ionic exchange experiments were performed to evaluate the ionic exchange capacity for the materials and assess their characteristics with or without oxidation for the cellulose structure. Using $25 \mathrm{~mL}$ of a $3 \mathrm{mmol} \mathrm{L}^{-1}$ $\mathrm{Ca}^{2+}$ solution in triplicates, samples were added: 1 piece weighting $5 \mathrm{mg}$ for cellulose cartridges; 1 piece weighting $15 \mathrm{mg}$, for composite cartridges; and for zeolite powder samples, $10 \mathrm{mg}$. After $30 \mathrm{~min}$ stirring in an orbital shaker at $250 \mathrm{rpm}$ and RT, the samples were centrifuged and the residual concentration was determined by flame photometry, Analyser 910M (São Paulo, Brazil) and liquefied petroleum gas (LPG). For the analysis, the 
concentration range was $0-100 \mathrm{mg} \mathrm{L}^{-1}$ and results are expressed as removal percentage for $\mathrm{Ca}^{2+}$.

\section{Results and Discussion}

The samples containing zeolite A, $\mathrm{X}$ and cellulose were analyzed using PXRD to identify the crystalline phases and to evaluate possible changes in the structure of the materials with the cartridges formation as presented in Figure 2.

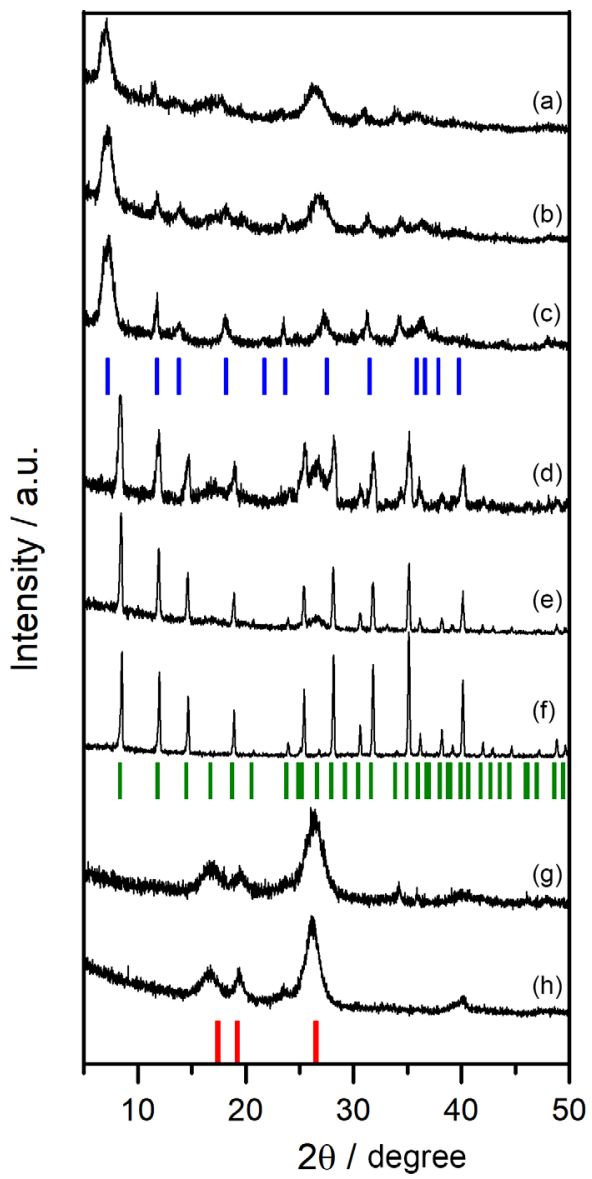

Figure 2. XRD patterns of (a) $\mathrm{C}_{\text {oxi }} \mathrm{X}$, (b) $\mathrm{C}_{0} \mathrm{X}$, (c) zeolite $\mathrm{X}$, (d) $\mathrm{C}_{\text {oxi }} \mathrm{A}$,

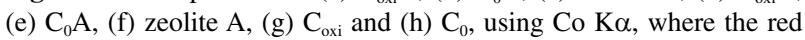
lines represent the peaks positions for cellulose, dark blue, zeolite $\mathrm{X}$ and green, zeolite A.

The cellulose by itself keeps its $2 \theta$ peaks position referent to the cellulose I $\alpha$ as main crystalline phase (CSDS 792796) ${ }^{21}$ as well as the relative intensity, indicating that the crystallinity of the samples is maintained even after the oxidation, ${ }^{19}$ as observed in Figures $2 \mathrm{~g}$ and $2 \mathrm{~h}$. Regarding the crystallinity, using the software Diffrac.EVA V4.0, it was possible to evaluate quantitatively this feature and for $\mathrm{C}_{\text {oxi }}$, the measured value was only ca. $12 \%$ lower than $\mathrm{C}_{0}$. The broad full width at half maximum (FWHM) for the main peaks of both cellulose samples, is consistent with the nanometric scale of the fibrils. ${ }^{22}$
The zeolites diffractograms present characteristic peaks for zeolite A (Figure 2f, ICSD 86644) ${ }^{23}$ and zeolite X (Figure 2c, ICSD 31541$)^{24}$ as pure phases. The comparison with the composites shows that the main peaks remain in the same $2 \theta$ values and the crystalline phases do not change during the cartridges formation as observed for similar composites. ${ }^{13,25}$ The assessment with the relative intensities to the set of composites containing the same zeolite type reveals for zeolite $A$ that the non-oxidized sample $\left(\mathrm{C}_{0} \mathrm{~A}\right.$, Figure $2 \mathrm{e}$ ) presents more intense peaks than the oxidized one $\left(\mathrm{C}_{\text {oxi }} \mathrm{A}\right.$, Figure $\left.2 \mathrm{~d}\right)$, which can be explained by the presence of crystals agglomerations in the former, ${ }^{26}$ as it will be further detailed in the SEM results. This feature is not observed to zeolite $\mathrm{X}$ composite samples $\left(\mathrm{C}_{0} \mathrm{X}\right.$, Figure $2 \mathrm{~b}$ and $\mathrm{C}_{\text {oxi }} \mathrm{X}$, Figure $2 \mathrm{a}$ ) mainly due to its nanometric size in the same range that the cellulose, so the interaction with the energy is similar, even changing their dispersion on the cartridges.

From the infrared spectra, it is possible to identify the main bands of the neat materials and thus, by considering band shifts, to infer important properties associated to the formation of the composites, as presented in Figure 3.

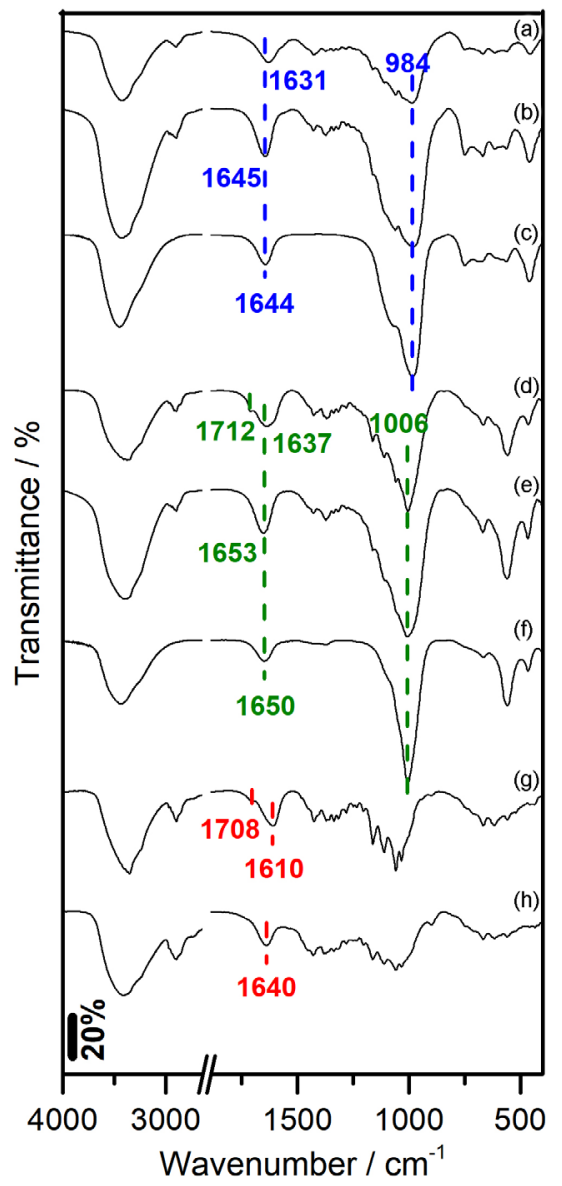

Figure 3. FTIR spectra of (a) $\mathrm{C}_{\text {oxi }} \mathrm{X}$, (b) $\mathrm{C}_{0} \mathrm{X}$, (c) zeolite $\mathrm{X}$, (d) $\mathrm{C}_{\text {oxi }} \mathrm{A}$, (e) $\mathrm{C}_{0} \mathrm{~A}$, (f) zeolite $\mathrm{A}$, (g) $\mathrm{C}_{\text {oxi }}$ and (h) $\mathrm{C}_{0}$ in $\mathrm{KBr}$. 
The samples spectra present the characteristic bands of the zeolites: the bands $1650 \mathrm{~cm}^{-1}$, zeolite A (Figure 3f) and $1644 \mathrm{~cm}^{-1}$, zeolite $\mathrm{X}$ (Figure 3c) related to the $\mathrm{O}-\mathrm{H}$ vibrations of adsorbed water in the nanoporous structure ${ }^{27}$ and the bands 1006 and $984 \mathrm{~cm}^{-1}$, respectively, related to the $\mathrm{O}-\mathrm{T}-\mathrm{O}(\mathrm{T}=\mathrm{Si}$ or $\mathrm{Al})$ asymmetric stretching in the aluminosilicate structure. ${ }^{28,29}$ The composite samples for the zeolite $\mathrm{A}\left(\mathrm{C}_{0} \mathrm{~A}\right.$, Figure $3 \mathrm{e}$ and $\mathrm{C}_{\mathrm{oxi}} \mathrm{A}$, Figure $\left.3 \mathrm{~d}\right)$ and zeolite $\mathrm{X}\left(\mathrm{C}_{0} \mathrm{X}\right.$, Figure $3 \mathrm{~b}$ and $\mathrm{C}_{\mathrm{oxi}} \mathrm{X}$, Figure $\left.3 \mathrm{a}\right)$ keep the bands related to zeolitic structure, also in lower wavenumbers values. ${ }^{30}$

The $\mathrm{C}_{0}$ (Figure $3 \mathrm{~h}$ ) and $\mathrm{C}_{\text {oxi }}$ (Figure $3 \mathrm{~g}$ ) spectra present the same wavenumber values to the bands related to the glucosidic structure ${ }^{16,18,31}$ and the main feature relies on the change of the $1640 \mathrm{~cm}^{-1}$ band, related to deformation of the $\mathrm{OH}$ groups in the cellulose structure and interlayer stretching, ${ }^{30,32}$ to $1610 \mathrm{~cm}^{-1}(\mathrm{C}=\mathrm{O}$ stretching in the carboxylate group $)^{33,34}$ and $1708 \mathrm{~cm}^{-1}(\mathrm{C}=\mathrm{O}$ ester linkages stretching for the acid form ${ }^{35,36}$ after the reaction using TEMPO as catalyst. The partial oxidation of the structure also promotes the narrowing of the $3400 \mathrm{~cm}^{-1}$ band, due to modification in the hydrogen bonds, both intra and intermolecular, caused by the carboxyl group insertion in the structure. ${ }^{36,37}$ An additional feature observed from the FTIR results is the efficiency for the initial $\mathrm{NaOH}$ treatment of $\mathrm{BC}$ pellicles, since some residual biomass from the bacteria or culture medium components can be identified from bands located at 1650 and $1580 \mathrm{~cm}^{-1}$, and both the cellulose samples do not present them. ${ }^{38}$

The cellulose structure presents shifting to higher wavenumbers in the bands located at the $1600-1750 \mathrm{~cm}^{-1}$ region. The band around $1640 \mathrm{~cm}^{-1}$ for $\mathrm{C}_{0}$ (Figure 3h), shifts to higher numbers in the $\mathrm{C}_{0} \mathrm{~A}$ (Figure $3 \mathrm{e}$ ) and $\mathrm{C}_{0} \mathrm{X}$ (Figure $3 \mathrm{~b}$ ). The oxidized composite samples also present higher wavenumbers when compared to the $\mathrm{C}_{\text {oxi }}$ sample (Figure 3g), and the $\mathrm{C}_{\text {oxi }} \mathrm{X}$ (Figure 3a) does not show the peak related to the acid groups formed after oxidation, probably due to the basic medium formed during the impregnation. The bands in the $3400 \mathrm{~cm}^{-1}$ region also present shifting in the composites, for changes in the hydrogen bondings with the insertion of the nanoporous materials. ${ }^{16}$

Another evidence of the effective cellulose oxidation is the conductimetry titration presented in Figure S1 (Supplementary Information (SI) section). The intersection from the red lines results on the volumes required to neutralize the strong acid $\left(\mathrm{V}_{0}=12.8 \mathrm{~mL}\right)$ and the weak acid $\left(\mathrm{V}_{1}=25.75 \mathrm{~mL}\right)$. Thus, $0.52 \mathrm{mmol} \mathrm{g}^{-1}$ of carboxylate groups are formed on the structure (or degree of oxidation, DO, $8.46 \%$ ), like values reported in literature to different cellulose samples. ${ }^{36,39,40}$ A similar measurement for the non-oxidized sample would present essentially a strong acid neutralization, since the $\mathrm{C}_{0}$ sample present very low carboxylate content.

This can be better observed using NMR, as presented in Figure S2 (SI section) for ${ }^{13} \mathrm{C}$ magic-angle spinning (MAS)-NMR. Differences for the oxidation are not visualized and the peaks positions to all the samples remain the same, with major changes related to the relative intensities for the surface peaks ( $85 \mathrm{ppm}$ for carbon 4 and 62 ppm for carbon 6$)^{41}$ that in the composites become more prominent. This indicates the interaction on the surface, as suggested for the IR results, between the non-oxidized cellulose fibers and the zeolites by hydrogen bonding. With the oxidized fibers, such groups present a slightly higher difference in such peaks, suggesting that the interaction in the cartridges is to some degree, more intense specially due to the carboxylate groups.

For ${ }^{29} \mathrm{Si}$ MAS-NMR spectra for zeolite A (Figure S3, SI section), the main peak corresponds to $\mathrm{Q}^{4}(4 \mathrm{Al})$ and since the $\mathrm{Si} / \mathrm{Al}$ ratio $>1.0$ (obtained previously from XRD Rietveld refinement and energy-dispersive $\mathrm{X}$-ray spectroscopy (EDS), as presented in our previous work), ${ }^{14}$ a small amount of $\mathrm{Q}^{4}(3 \mathrm{Al})$ can be observed at -89 ppm. ${ }^{42,43}$ Surface silanol groups are usually attributed to the left side signal for this zeolite. Both the signals move slightly on the composites spectra strongly indicating the interaction to the cellulose fibers through such groups. Observing the zeolite $\mathrm{X}$ composites, $\mathrm{C}_{\text {oxi }} \mathrm{X}$ and $\mathrm{C}_{0} \mathrm{X}$ show the same positions for the observed peaks and changes in the relative intensity to the last peaks. It is known that the groups $\mathrm{Q}^{4}(4 \mathrm{Al})$ and $\mathrm{Q}^{4}(3 \mathrm{Al})$ are present mainly on the bulk for the zeolite $\mathrm{X}$ crystals and the $\mathrm{Q}^{4}(2 \mathrm{Al})$ and $\mathrm{Q}^{4}(1 \mathrm{Al})$ groups also present the surface silanol groups contribution. ${ }^{44}$ In both the samples, the peaks $\mathrm{Q}^{4}(1 \mathrm{Al})$ and $\mathrm{Q}^{4}(0 \mathrm{Al})$ decrease slightly their relative intensities indicating such surface silanol groups taking part on the interaction with both cellulose samples.

The ${ }^{27} \mathrm{Al}$ MAS-NMR spectra (Figure 4) of the samples show the presence of tetracoordinated aluminum around $60 \mathrm{ppm},{ }^{42,45}$ without any shifts to this peak for zeolite A and its composites. The minor changes that occur for the $\mathrm{Si}$ environment are mostly on the surface and do not promote visible changes to the zeolite A bulk. Zeolite $\mathrm{X}$ on its turn, for being a nanometric particle, presents a slight shift to lower fields from 60 to $62 \mathrm{ppm}$, since the interactions happen using the silanol groups on the surface, the angle for the Al-O-Si bonds will also present changes causing a higher chemical shift to the composite samples. Thus, in addition to the IR results, we can infer that the zeolites interact with the cellulose specially by hydrogen bondings that happen via the silanol groups and the hydroxyl and carboxilate for the cellulose. 


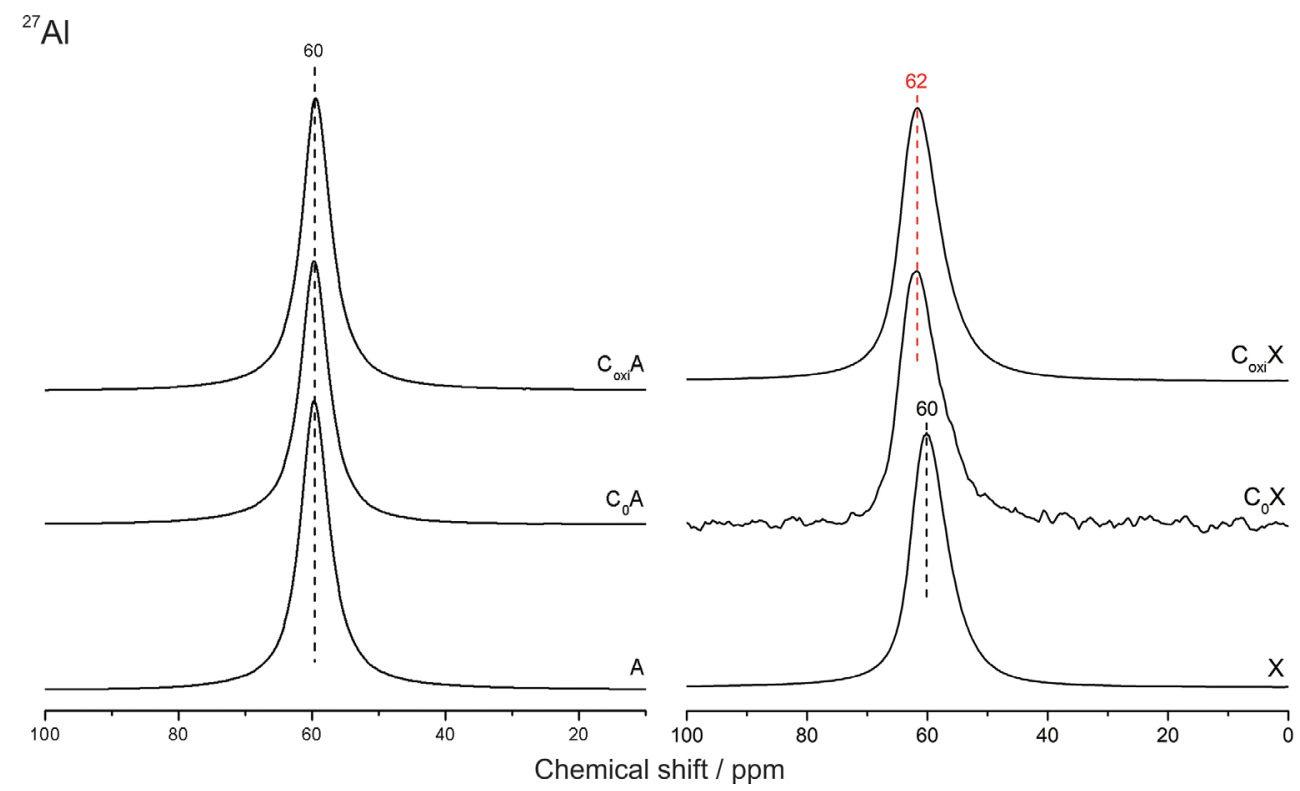

Figure 4. ${ }^{27} \mathrm{Al}$ MAS-NMR spectra for the zeolites $\mathrm{A}$ and $\mathrm{X}$ with their composites.
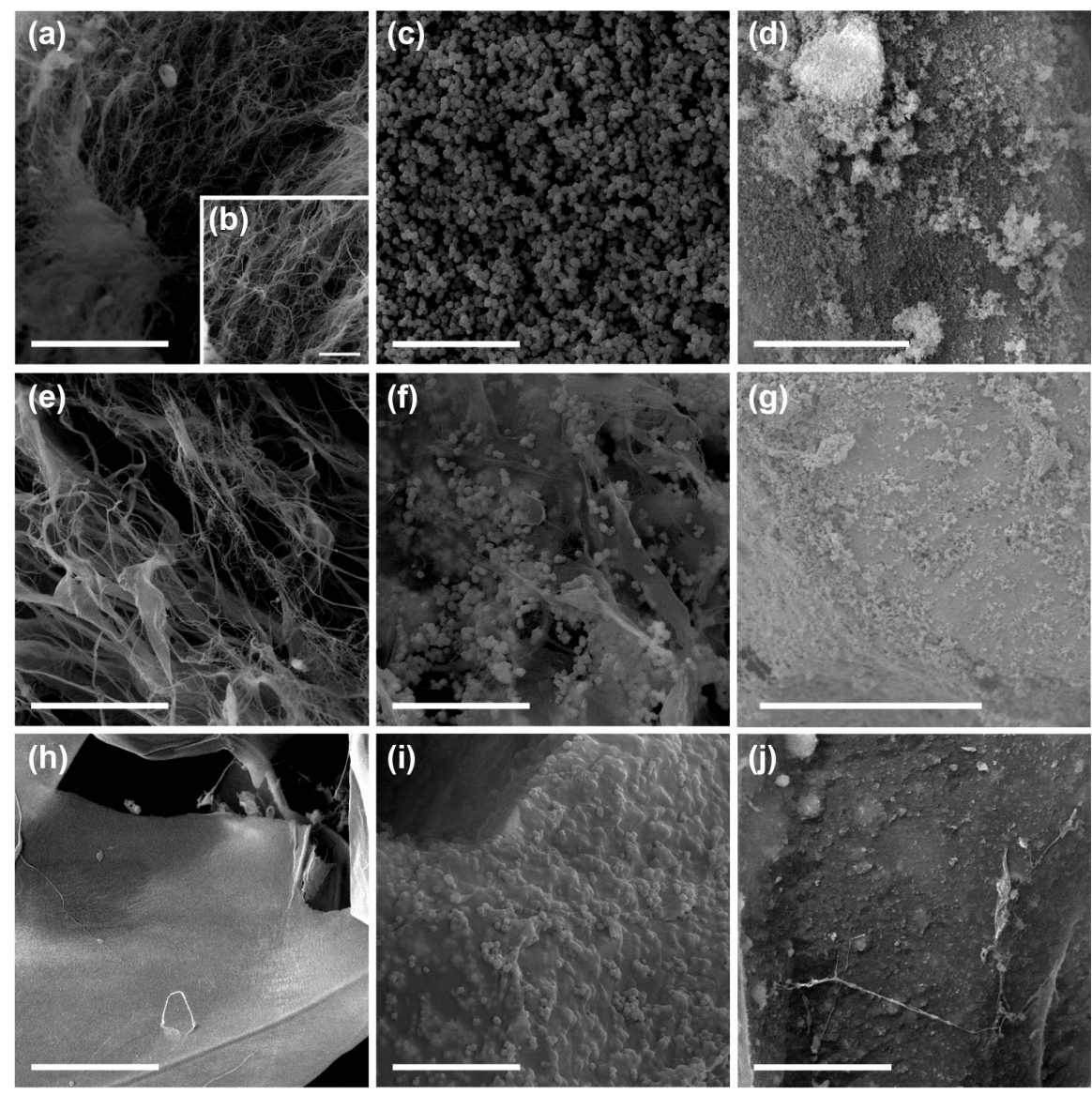

Figure 5. SEM images of (a, b) BC pellicles, (c) zeolite A, (d) zeolite $\mathrm{X}$, (e) $\mathrm{C}_{0}$, (f) $\mathrm{C}_{0} \mathrm{~A}$, (g) $\mathrm{C}_{0} \mathrm{X}$, (h) $\mathrm{C}_{\text {oxi }}$, (i) $\mathrm{C}_{\text {oxi }} \mathrm{A}$ (j) $\mathrm{C}_{\text {oxi }} \mathrm{X}$. The scale bars correspond to $20 \mu \mathrm{m}$ except for $\mathrm{b}(5 \mu \mathrm{m})$.

The SEM images (Figure 5) of the samples present the main morphological characteristics observed to the raw and composite materials. Zeolite A (Figure 5c) is formed by homogeneous cubic crystals of ca. $1 \mu \mathrm{m}$, characteristics of this zeolite type. ${ }^{28,46}$ Zeolite X (Figure 5d) in turn, even using higher magnification values, is not well-defined using SEM due to its small size (in the range of nanometers). Thus, it is possible to verify agglomeration and possible 
monodisperse circular disks, but its size and shape cannot be assessed properly. ${ }^{47}$

The cellulose samples are presented in the first column of the Figure 5 and it is possible to see the differences between the BC pellicle and the cartridges. The pellicle (Figures 5a and 5b) is essentially the nanofibrils forming a web. The disassembling step and adjustment in the cellulose content promotes some fibers to connect each other in thin sheets for the $\mathrm{C}_{0}$ sample (Figure 5e) but a considerable part of them remain as nanofibrils connecting these sheets and loose through the cartridges structure. In the oxidized sample, $\mathrm{C}_{\text {oxi }}$ Figure $5 \mathrm{~h}$, the most part of the fibrils are found in well-assembled sheets formed during the freezing step where the fast ice crystals growing in the system push the fibrils and their surface charge keeps them linked with each other. ${ }^{48}$ Higher magnifications observation suggests small voids (or mesopores) between these fibers and possibly, improved accessibility of molecules to the active sites of the material when the zeolites are added to this matrix..$^{33,46}$ The sheets formation is better observed to the oxidized samples, including the composite ones, with big voids between these sheets forming connected macropores.

The non-oxidized composites are presented in the second row of the Figure $5, \mathrm{C}_{0} \mathrm{~A}$ (Figure 5f) and $\mathrm{C}_{0} \mathrm{X}$ (Figure $5 \mathrm{~g}$ ). The sheets are better assembled to the composites than to the cellulose sample $\left(\mathrm{C}_{0}\right.$, Figure $\left.5 \mathrm{e}\right)$. The zeolite crystals get agglomerated and the most part of them are accessible on the surface. The oxidized composites, on the other hand, present the sheets with the particles embedded on them observing roughness on the surface on Figure $5 \mathrm{i}\left(\mathrm{C}_{\text {oxi }} \mathrm{A}\right)$ and Figure $5 \mathrm{j}\left(\mathrm{C}_{\text {oxi }} \mathrm{X}\right)$.

The main thermal events identified to the studied samples and their weight loss are presented in Table 1 and all the individual TGA graphs along with their derivative analyses are presented in Figure S4 (SI section). The aluminosilicate materials present low weight loss and the main event related to the water evaporation from the channels and pores. ${ }^{46,49}$ The main event in the cellulose samples is related to cellulose degradation reactions ${ }^{50}$ and the comparison between the non-oxidized $\left(\mathrm{C}_{0}\right)$ and oxidized $\left(\mathrm{C}_{\text {oxi }}\right)$ samples reveal it happening in lower temperatures in the last sample, with similar ashes formation. It can be attributed to the weakening of the hydrogen bonds on the cellulose chains due to the exchange of the primary hydroxyl for the polar carboxylate or carboxylic groups. ${ }^{40,51}$ The same effect is observed even when the zeolites are incorporated into the cellulose matrix.

It also can be noticed that the composite cartridges present lower weight loss (as expected with the increment of a more stable material in the carbonic structure) and differences related to the main event. The comparison between the composite cartridges containing the same zeolite also shows lower weight loss with discrepancies of ca. $10 \%$ to the non-oxidized samples with the most prominent changes to zeolite $\mathrm{X}>$ zeolite A. This sample order is seen in the SEM as the particles that fit better inside the cellulose sheets, due to their shape.

It is known that aerogels have great insulating properties and among the samples, the non-oxidized samples are the most related to aerogels, with thin fibers or sheets. The aluminosilicate materials also present insulating properties and the combination of these materials can be responsible for better insulating properties to the composites. ${ }^{11,26}$ Even though, the cellulose oxidation does not cause a big issue to the required application, since the lowest temperature observed to the cartridge's degradation is still higher than the most part of temperature used for many gas and water adsorption processes ${ }^{52}$ and this feature does not exclude these samples to this use.

Regarding the ionic exchange experiments presented in Figure 6 and Table S3 (SI section), the zeolites and the composites present a better removal behavior for $\mathrm{Ca}^{2+}$ than it was expected, whilst the cellulose cartridges did not exhibit any removal, even that they have some sodium content (around 16\%). Usually, nanocellulose-based materials present functional groups or molecules grafted to surface hydroxyl groups, improving the adsorptive properties for several pollutants. ${ }^{53}$ Mautner et al. ${ }^{54}$ performed some

Table 1. Main thermal events for the samples analyzed with synthetic air, flow $50 \mathrm{~mL} \mathrm{~min}^{-1}$, heating hate $10^{\circ} \mathrm{C}$ min ${ }^{-1}$

\begin{tabular}{|c|c|c|c|c|c|}
\hline \multirow{2}{*}{ Sample } & \multicolumn{3}{|c|}{ Main thermal event } & \multirow{2}{*}{ Event weight loss / \% } & \multirow{2}{*}{ Total weight loss / \% } \\
\hline & $\mathrm{T}_{\mathrm{i}} /{ }^{\circ} \mathrm{C}$ & $\mathrm{T}_{\mathrm{f}} /{ }^{\circ} \mathrm{C}$ & $\mathrm{T}_{\max } /{ }^{\circ} \mathrm{C}$ & & \\
\hline$\overline{\mathrm{C}_{0}}$ & 210 & 363 & 313 & 69.4 & 99.6 \\
\hline $\mathrm{C}_{\text {oxi }}$ & 170 & 315 & 280 & 69.1 & 98.0 \\
\hline Zeolite A & 25 & 215 & 135 & 17.5 & 24.6 \\
\hline $\mathrm{C}_{0} \mathrm{~A}$ & 193 & 357 & 300 & 27.0 & 45.0 \\
\hline $\mathrm{C}_{\mathrm{oxi}} \mathrm{A}$ & 185 & 310 & 276 & 32.0 & 55.1 \\
\hline Zeolite X & 30 & 271 & 131 & 22.8 & 26.4 \\
\hline $\mathrm{C}_{0} \mathrm{X}$ & 255 & 377 & 332 & 28.1 & 50.1 \\
\hline $\mathrm{C}_{\mathrm{oxi}} \mathrm{X}$ & 201 & 323 & 312 & 36.7 & 58.9 \\
\hline
\end{tabular}

$\mathrm{T}_{\mathrm{i}}$ : initial temperature for the thermal event; $\mathrm{T}_{\mathrm{f}}$ : final temperature; $\mathrm{T}_{\max }:$ maximum observed for the event; $\mathrm{C}_{0}$ : non-oxidized samples; $\mathrm{C}_{\mathrm{oxi}}:$ oxidized samples. 
studies using nanopapers formed by oxidized cellulose nanofibrils functionalized with phosphoric groups to act as ionic exchange membranes and they found good adsorption capacities due to the presence of $\mathrm{H}_{2} \mathrm{PO}_{3}$ linked through carboxylate groups. However, they suggest that adsorption preferably takes place on the surface and is less favored within the nanopaper bulk. Thus, the sodium not exchanged for this process can be attributed to their encapsulation inside the cellulose sheets, not on the surface.

When compared to their respective composites, the measured values were also higher than expected. The red and blue lines in Figure 6 point to the amount that should be exchanged considering the real value obtained for the zeolite; for example, zeolite A showed $65 \%$ removal which means that considering the percentage of zeolite in the composite sample and that the cellulose would not have effect on it, the cartridges should have $43 \%$ removal equally. The positive effect that the cellulose had to the $\mathrm{Ca}^{2+}$ removal is more pronounced to the non-oxidized cellulose, according to such results.

Zeolite A is the most common zeolite in water softening applications due to its low $\mathrm{Si} / \mathrm{Al}$ and consequently high ionic exchange. The removal depends on different parameters like temperature, adsorbent dosage, initial concentration of adsorbate, stirring speed, $\mathrm{pH}$ and zero point charge for the material. ${ }^{55}$ This makes comparison to the literature harder but it can also be used to optimize the process. For example, Aragaw and Ayalew ${ }^{1}$ recently reported zeolite $\mathrm{X}$ from kaolin for water softening. Without any optimization, around 37.2\% of removal was obtained, whilst depending on the time and temperature, around $100 \%$ was achieved. Studying magnetic zeolites, our group assessed the water softening for composites with magnetite nanoparticles obtaining between 90 and 99\% of removal, with decrease correspondent to the weight of nonadsorbent material. ${ }^{28}$ In our last paper, ${ }^{14}$ aerogel-like materials with a multiporous zeolite A show superior adsorptive behavior not only for the presence of the mesopores in the zeolite A crystal, but also to the presence of cellulose over the structures. Other authors also suggested the use of clinoptilolite for this purpose like Kouli et al..$^{56}$ that removed ca. $90 \%$ of the salinity from seawater after continuous cycles of use, and Liu et al. ${ }^{57}$ for groundwater, achieving the values required in regulatory parameters after 20-25 min in a fixed-bed system.

Figure S5 (SI section) presents SEM images of zeolite A composites facilitating the comparison of morphology to the cartridges before and after the ionic exchange experiments assessing leaching of the zeolites from the cartridges or even some changes to the nanofibers' organization. The results suggest that the structure is not changed after some time in aqueous medium at neutral $\mathrm{pH}$ and the proposed materials are stable. Thus, the materials can be used efficiently in aqueous systems without leaching the zeolite particles.

A recent critical review about waste resources, synthesis and applications for zeolite LTA, authored by Collins et al..$^{58}$ showed that this zeolite is currently used for water purification processes, from their demonstrated capacity for uptake of a wide range of water contaminants, although their weakness rely on diffusion limitations in zeolite micropores. On the other hand, they point the expansion of the water softening market and the development of hierarchical zeolites with increased mesoporosity can improve even more the application of such materials. The materials presented in this work show their relevance in this scenario and it anticipated that independently from the crystal size, other zeolitic structures can be used in addition to $\mathrm{BC}$ matrix for different applications.

\section{Conclusions}

In summary, we have successfully performed the synthesis of aerogel composite materials containing bacterial cellulose and nanoporous materials, in form of

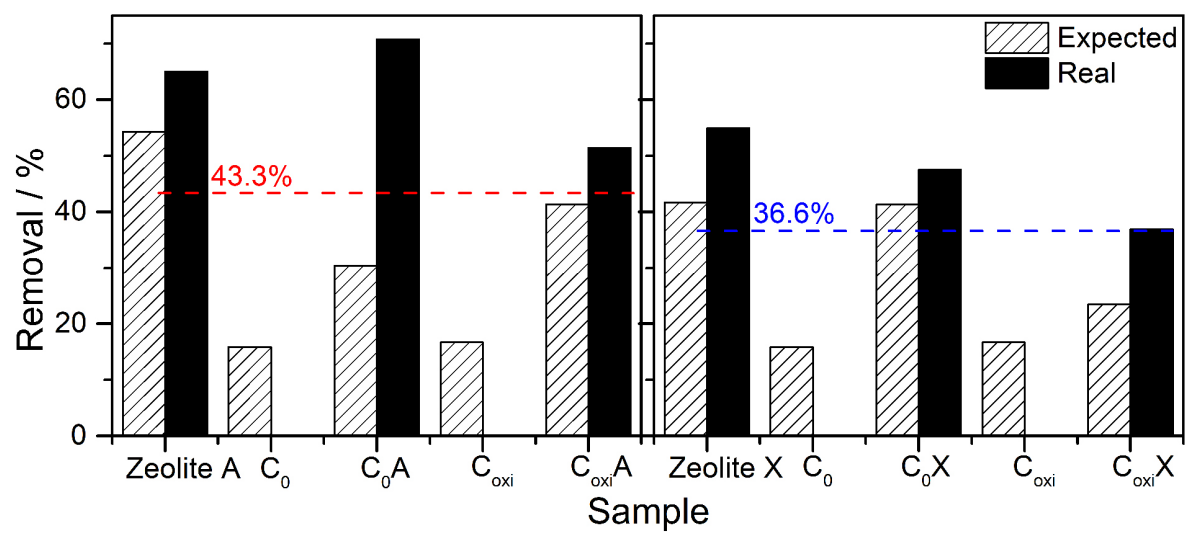

Figure 6. Removal results for ionic exchange with a $3 \mathrm{mmol} \mathrm{L}^{-1} \mathrm{Ca}^{2+}$ for $30 \mathrm{~min}$ at $250 \mathrm{rpm}$ in ambient conditions comparing cellulose samples $\left(\mathrm{C}_{0}\right.$ and $\left.\mathrm{C}_{\text {oxi }}\right)$ to zeolite $\mathrm{A}$ and its composites $\left(\mathrm{C}_{0} \mathrm{~A}\right.$ and $\left.\mathrm{C}_{\text {oxi }} \mathrm{A}\right)$ on the left side and to zeolite $\mathrm{X}$ and its composites $\left(\mathrm{C}_{0} \mathrm{X}\right.$ and $\left.\mathrm{C}_{\text {oxi }} \mathrm{X}\right)$ on the right side. The red signs present the expected removal values to the composites considering the zeolite A weight content in the cartridges, and in blue, to zeolite $\mathrm{X}$. 
hierarchical porous materials. Smaller particles seem to interact better with the cellulose structure of the cartridges, but in a general way, the insertion of aluminosilicate materials in this matrix promotes changes in the vibrations of the carboxylic groups for the oxidized samples, or the primary $-\mathrm{OH}$ in the non-oxidized samples. Improvements in the thermal behavior of the composites is also observed, as well as preservation of the crystalline structure.

Thus, the results have evidenced the oxidized cellulose as the one with homogeneity in the particles distribution through the sheets and from the ionic exchange measurements, we can anticipate the use of similar materials in both gas and aqueous adsorption systems.

\section{Supplementary Information}

Supplementary information (conductimetric titration, NMR spectra and tables, TGA and DTG curves, $\mathrm{Ca}^{2+}$ ionic exchange and SEM images after the experiments, Figures S1-S5 and Tables S1-S3) is available free of charge at http://jbcs.sbq.org.br as PDF file.

\section{Acknowledgments}

M. F. R. thanks the financial support FUNCAP/CNPq (PR2-0101-00023.01.00/15). A. L. S. P. thanks the CAPES (2017SLR-17925) for financial support. This study was financed in part by the Coordenação de Aperfeiçoamento de Pessoal de Nível Superior - Brazil (CAPES) - Finance Code 001, and process 88881.189392/2018-01. The authors would like to thank the Central Analítica-UFC/ CT-INFRA/MCTI-SISANO/Pró-Equipamentos CAPES for the support.

\section{References}

1. Aragaw, T. A.; Ayalew, A. A.; Water Pract. Tech. 2019, 14, 145.

2. Deierlein, A. L.; Teitelbaum, S. L.; Windham, G. C.; Pinney, S. M.; Galvez, M. P.; Caldwell, K. L.; Jarrett, J. M.; Gajek, R.; Kushi, L. H.; Biro, F.; Wolff, M. S.; Environ. Int. 2019, 122, 310; Zeng, X.; Xu, X.; Qin, Q.; Ye, K.; Wu, W.; Huo, X.; Environ. Geochem. Health 2019, 41, 309; Sarigiannis, D. A. In Environmental Indicators; Armon, R. H.; Hänninen, O., eds.; Springer Netherlands: Dordrecht, 2015.

3. Carolin, C. F.; Kumar, P. S.; Saravanan, A.; Joshiba, G. J.; Naushad, M.; J. Environ. Chem. Eng. 2017, 5, 2782; Fu, F.; Wang, Q.; J. Environ. Manage. 2011, 92, 407; World Health Organization (WHO); Guidelines for Drinking-Water Quality; WHO: Geneva, 2011, available at https://www.who.int/ water_sanitation_health/publications/2011/dwq_guidelines/ en/, accessed in May 2021; World Health Organization (WHO);
Hardness in Drinking-Water: Background Document for Development of WHO Guidelines for Drinking-Water Quality; WHO: Geneva, 2010, available at https://apps.who.int/iris/ handle/10665/70168, accessed in May 2021.

4. Kumar, V.; Kumar, S.; Kim, K.-H.; Tsang, D. C. W.; Lee, S.S.; Environ. Res. 2019, 168, 336; Tham, K. W.; Energy Build. 2016, 130, 637; Zhao, S.; Yi, H.; Tang, X.; Gao, F.; Zhang, B.; Wang, Z.; Zuo, Y.; J. Cleaner Prod. 2015, 87, 856; Zhao, Y.; Low, Z.-X.; Feng, S.; Zhong, Z.; Wang, Y.; Yao, Z.; Nanoscale 2017, 9, 5433; Mirasoli, M.; Gotti, R.; di Fusco, M.; Basaglia, G.; Fiori, J.; Roda, A.; J. Pharm. Biomed. Anal. 2017, 144, 236.

5. Mintova, S.; Barrier, N.; Verified Syntheses of Zeolitic Materials, $3^{\text {rd }}$ ed.; Elsevier (on behalf of the Synthesis Commission of the International Zeolite Association): Amsterdam, 2016.

6. Kerr, G. T.; J. Phys. Chem. 1968, 72, 2594.

7. Masaru, O.; Shin-Ya, S.; Junko, T.; Yasuto, N.; Eiichi, K.; Masahiko, M.; Chem. Lett. 2000, 29, 882.

8. Feliczak-Guzik, A.; Microporous Mesoporous Mater. 2018, 259, 33; Cychosz, K. A.; Guillet-Nicolas, R.; García-Martínez, J.; Thommes, M.; Chem. Soc. Rev. 2017, 46, 389.

9. Schwieger, W.; Machoke, A. G.; Weissenberger, T.; Inayat, A.; Selvam, T.; Klumpp, M.; Inayat,A.; Chem. Soc. Rev. 2016, 45, 3353.

10. Stumpf, T. R.; Yang, X.; Zhang, J.; Cao, X.; Mater. Sci. Eng., C 2018, 82, 372.

11. Bendahou, D.; Bendahou, A.; Seantier, B.; Grohens, Y.; Kaddami, H.; Ind. Crops Prod. 2015, 65, 374.

12. Valencia, L.; Rosas, W.; Aguilar-Sanchez, A.; Mathew, A. P.; Palmqvist, A. E. C.; ACS Appl. Mater. Interfaces 2019, 11, 40424.

13. Ma, X.; Lou, Y.; Chen, X.-B.; Shi, Z.; Xu, Y.; Chem. Eng. J. 2019, 356, 227.

14. Bessa, R. A.; França, A. M. M.; Pereira, A. L. S.; Alexandre, N. P.; Pérez-Page, M.; Holmes, S. M.; Nascimento, R. F.; Rosa, M. F.; Anderson, M. W.; Loiola, A. R.; Microporous Mesoporous Mater. 2021, 312, 110752.

15. Brandes, R.; Carminatti, C.; Mikowski, A.; Al-Qureshi, H.; Recouvreux, D.; J. Nano Res. 2017, 45, 142.

16. Andrade, F. K.; Morais, J. P. S.; Muniz, C. R.; Nascimento, J. H. O.; Vieira, R. S.; Gama, F. M. P.; Rosa, M. F.; Cellulose 2019, 26, 5851.

17. Hestrin, S.; Schramm, M.; Biochem. J. 1954, 58, 345.

18. Nascimento, E. S.; Pereira, A. L. S.; Barros, M. O.; Barroso, M. K. A.; Lima, H. L. S.; Borges, M. F.; Feitosa, J. P. A.; Azeredo, H. M. C.; Rosa, M. F.; Cellulose 2019, 26, 2291.

19. Saito, T.; Kimura, S.; Nishiyama, Y.; Isogai, A.; Biomacromolecules 2007, 8, 2485.

20. Pereira, A. L. S.; Feitosa, J. P. A.; Morais, J. P. S.; Rosa, M. D. F.; Carbohydr. Polym. 2020, 250, 116927; Saito, T.; Isogai, A.; Biomacromolecules 2004, 5, 1983.

21. Nishiyama, Y.; Sugiyama, J.; Chanzy, H.; Langan, P.; J. Am. Chem. Soc. 2003, 125, 14300. 
22. Dinnebier, R. E.; Billinge, S. J. L. In Powder Diffraction: Theory and Practice; Dinnebier, R. E.; Billinge, S. J. L., eds.; The Royal Society of Chemistry: Cambridge, 2008, p. 1.

23. Ikeda, T.; Izumi, F.; Kodaira, T.; Kamiyama, T.; Chem. Mater. 1998, 10, 3996.

24. Gallezot, P.; Beaumont, R.; Barthomeuf, D.; J. Phys. Chem. 1974, 78, 1550 .

25. Wei, X.-L.; Liang, S.; Xu, Y.-Y.; Sun, Y.-L.; An, J.-F.; Chao, Z.-S.; J. Membrane Sci. 2017, 530, 240.

26. Soheilmoghaddam, M.; Wahit, M. U.; Tuck Whye, W.; Ibrahim Akos, N.; Heidar Pour, R.; Ali Yussuf, A.; Carbohydr. Polym. 2014, 106, 326.

27. Youssef, H. F.; Hegazy, W. H.; Abo-Almaged, H. H.; J. Porous Mater. 2015, 22, 1033; Rasouli, M.; Yaghobi, N.; Chitsazan, S.; Sayyar, M. H.; Microporous Mesoporous Mater. 2012, 152, 141.

28. Bessa, R. A.; Costa, L. S.; Oliveira, C. P.; Bohn, F.; Nascimento, R. F.; Sasaki, J. M.; Loiola, A. R.; Microporous Mesoporous Mater. 2017, 245, 64.

29. Zhao, X.; Meng, X.; Shang, Y.; Song, Y.; Liu, R.; Wei, J.; Gong, Y.; Li, Z.; Microporous Mesoporous Mater. 2018, 264, 92.

30. Sanaeepur, H.; Kargari, A.; Nasernejad, B.; Ebadi Amooghin, A.; Omidkhah, M.; J. Taiwan Inst. Chem. Eng. 2016, 60, 403.

31. Wang, S.-S.; Han, Y.-H.; Ye, Y.-X.; Shi, X.-X.; Xiang, P.; Chen, D.-L.; Li, M.; RSC Adv. 2017, 7, 45145.

32. Araújo, I. M. S.; Silva, R. R.; Pacheco, G.; Lustri, W. R.; Tercjak, A.; Gutierrez, J.; Júnior, J. R. S.; Azevedo, F. H. C.; Figuêredo, G. S.; Vega, M. L.; Ribeiro, S. J. L.; Barud, H. S.; Carbohydr. Polym. 2018, 179, 341.

33. Jiang, F.; Dinh, D. M.; Hsieh, Y.-L.; Carbohydr. Polym. 2017, 173, 286.

34. Kamal Mohamed, S. M.; Ganesan, K.; Milow, B.; Ratke, L.; RSC Adv. 2015, 5, 90193; Li, Z.; Wang, L.; Hua, J.; Jia, S.; Zhang, J.; Liu, H.; Carbohydr. Polym. 2015, 120, 115.

35. Lavoine, N.; Bras, J.; Saito, T.; Isogai, A.; Macromol. Rapid Commun. 2016, 37, 1033; Lu, Q.-L.; Li, X.-Y.; Tang, L.-R.; Lu, B.-L.; Huang, B.; RSC Adv. 2015, 5, 56198; Ruan, C.-Q.; Stromme, M.; Mihranyan, A.; Lindh, J.; RSCAdv. 2017, 7, 40600.

36. Jia, Y.; Zhai, X.; Fu, W.; Liu, Y.; Li, F.; Zhong, C.; Carbohydr. Polym. 2016, 151, 907.

37. Duarte, E. B.; Chagas, B. S.; Andrade, F. K.; Brígida, A. I. S.; Borges, M. F.; Muniz, C. R.; Souza Filho, M. S. M.; Morais, J. P. S.; Feitosa, J. P. A.; Rosa, M. F.; Cellulose 2015, 22, 3177; Tserki, V.; Zafeiropoulos, N. E.; Simon, F.; Panayiotou, C.; Composites, Part A 2005, 36, 1110.

38. Fuller, M. E.; Andaya, C.; Mcclay, K.; J. Microbiol. Methods 2018, 144, 145.

39. Saito, T.; Isogai, A.; Carbohydr. Polym. 2005, 61, 183; Besbes, I.; Alila, S.; Boufi, S.; Carbohydr. Polym. 2011, 84, 975.

40. Isogai, A.; Saito, T.; Fukuzumi, H.; Nanoscale 2011, 3, 71.

41. Castro, C.; Zuluaga, R.; Putaux, J.-L.; Caro, G.; Mondragon, I.; Gañán, P.; Carbohydr. Polym. 2011, 84, 96; Meza-Contreras,
J. C.; Manriquez-Gonzalez, R.; Gutiérrez-Ortega, J. A.; Gonzalez-Garcia, Y.; Carbohydr. Res. 2018, 461, 51; Lai, C.; Zhang, S.; Chen, X.; Sheng, L.; Cellulose 2014, 21, 2757.

42. Xue, Z.; Ma, J.; Hao, W.; Bai, X.; Kang, Y.; Liu, J.; Li, R.; J. Mater. Chem. 2012, 22, 2532.

43. Greiser, S.; Sturm, P.; Gluth, G. J. G.; Hunger, M.; Jäger, C.; Ceram. Int. 2017, 43, 2202.

44. Medeiros-Costa, I. C.; Laroche, C.; Pérez-Pellitero, J.; Coasne, B.; Microporous Mesoporous Mater. 2019, 287, 167.

45. Morales-Pacheco, P.; Alvarez, F.; Bucio, L.; Domínguez, J. M.; J. Phys. Chem. C 2009, 113, 2247; Etim, U. J.; Bai, P.; Wang, Y.; Subhan, F.; Liu, Y.; Yan, Z.; Appl. Catal., A 2019, 571, 137.

46. Moreira, J. C.; Boca Santa, R. A. A.; Miraglia, G. L.; Soares, C.; Riella, H. G.; Microporous Mesoporous Mater. 2019, 279, 262.

47. Sivalingam, S.; Sen, S.; Appl. Surf. Sci. 2019, 463, 190; Sivalingam, S.; Sen, S.; Environ. Sci. Pollut. Res. 2019, 26, 34693.

48. Donius, A. E.; Liu, A.; Berglund, L. A.; Wegst, U. G. K.; J. Mech. Behav. Biomed. Mater. 2014, 37, 88; Sehaqui, H.; Salajkova, M.; Zhou, Q.; Berglund, L. A.; Soft Matter 2010, 6, 1824.

49. Lin, G.; Zhuang, Q.; Cui, Q.; Wang, H.; Yao, H.; Chin. J. Chem. Eng. 2015, 23, 1768.

50. Vasconcelos, N. F.; Feitosa, J. P. A.; da Gama, F. M. P.; Morais, J. P. S.; Andrade, F. K.; de Souza Filho, M. D. S. M.; Rosa, M. D. F.; Carbohydr. Polym. 2017, 155, 425; Vazquez, A.; Foresti, M. L.; Cerrutti, P.; Galvagno, M.; J. Polym. Environ. 2013, 21, 545; Mohammadkazemi, F.; Azin, M.; Ashori, A.; Carbohydr. Polym. 2015, 117, 518.

51. Lai, C.; Sheng, L.; Liao, S.; Xi, T.; Zhang, Z.; Surf. Interface Anal. 2013, 45, 1673.

52. Ma, X.; Liu, H.; Li, W.; Peng, S.; Chen, Y.; RSC Adv. 2016, 6 , 96997; Anis, S. F.; Hashaikeh, R.; Hilal, N.; Desalination 2019, 468, 114077; Liu, Q.; Ke, M.; Liu, F.; Yu, P.; Hu, H.; Li, C.; RSC Adv. 2017, 7, 22892.

53. Voisin, H.; Bergström, L.; Liu, P.; Mathew, A. P.; Nanomaterials 2017, 7, 57.

54. Mautner, A.; Kobkeatthawin, T.; Mayer, F.; Plessl, C.; Gorgieva, S.; Kokol, V.; Bismarck, A.; Nanomaterials 2019, 9, 136.

55. Nascimento, R. F.; Lima, A. C. A.; Vidal, C. B.; Melo, D. Q.; Raulino, G. S. C.; Adsorção: Aspectos Teóricos e Aplicações Ambientais; Imprensa Universitária da Universidade Federal do Ceará (UFC): Fortaleza, CE, 2020.

56. Kouli, M. E.; Banis, G.; Tsarabaris, P.; Ferraro, A.; Hristoforou, E.; J. Magn. Magn. Mater. 2018, 465, 692.

57. Liu, W.; Singh, R. P.; Jothivel, S.; Fu, D.; Environ. Sci. Pollut. Res. 2020, 27, 17541.

58. Collins, F.; Rozhkovskaya, A.; Outram, J. G.; Millar, G. J.; Microporous Mesoporous Mater. 2020, 291, 109667.

Submitted: January 29, 2021

Published online: May 14, 2021 